\title{
BEHIND DOMESTIC LIFE, A POSTWAR MIDDLE-CLASS HOME: THE MILLER HOUSE IN GAINESVILLE, FL
}

\author{
Filiz SÖNMEZ*
}

Received: 23.08.2013; Final Text: 21.01.2014

Keywords: Home; dwelling culture and space; oral history; narrative research techniques.

\section{INTRODUCTION}

In the recent history of the modernization of dwelling culture, much attention has been given to domestic life. However, less research has been done on domestic everyday life and very little on actual homeowners' firsthand experiences in their home.

The intention of this study is to 'subjectively approach' a modern house of the 1950s in order to reveal the personal experiences of the family by utilizing oral history and narrative research techniques. This will be possible through a case study of a single Gainesville house and family, intended to contribute to a larger corpus of data documenting the lived, subjective, social, cultural, and dialectical experiences of domestic life during the postwar era. Rather than looking at the wealthy homes that are usually highlighted in architectural journals of the 1950s, this study will focus on a middle class house.

The overall aim of this study is to examine how the Millers, as individuals, used their home in the 1950s and the relationship between the space they inhabited and their domestic desires. Therefore, utilizing the interviews with Paul Miller, I will attempt to reconstruct and analyze the physical space of the Miller house. In addition to this reconstruction, a floorplan and various photographs will be used to demonstrate the actual family life lived within that space. Additionally, special attention will be given to the usage of the space with a particular focus on Paul Miller, who lived there longer than any of the other homeowners.

When we examine the home objectively it appears to be uncomplicated and mundane, but when we take the most recent approach, a subjective analysis placing importance on the social meanings of the domestic space, we see that it is far more sophisticated and complex, affecting and revealing an array of personal habits, desires, and tastes. By utilizing this contemporary approach we can get a better sense of the domestic space because rather
* Department of Architecture, Erciyes University, Kayseri, TURKEY. 
1. Oral history technique includes interviewing many kinds of people or groups to obtain information about what it was like to live during a particular time. Namely, oral history collects memories and personal commentaries of historical significance through recorded interviews. (Ritchie, 2003, 19).

2. This method was used before in Loeb's (2003) study similarly. This study reconstructed and analyzed the physical space of the deLemos apartment, based on interviews. Like in our analysis, it was attempted to piece together a plan and provide a sketch of space utilization, while at the same time giving a sense of the actual family life within that space. Loeb (2003) (Cited in Lane (2007, 94-102)).

In addition, "an interview with people who live in this house", which is an article title written in 1955 in House Beautiful magazine, mentions about how people use their home. With this story, House Beautiful $(1955,182)$ departs from its usual presentation of a house and offers instead this moving report from one of its editors.

The Miller House's analysis, with access to a view within the room and the lifestyle, also recalls the empowered liminality of the everyday life, as examined by Lefebvre in The Critique of Everyday Life. Lefebvre touched on the staged relm of domestic life. Another study is Bryson's (2010) book, At Home, A Short History of Private Life, Bryson (2010) considered about home and ordinary things of life and domestic life. He formed the idea of journeying about his house from room to room to "write a history of the world without leaving home." He showed how each room has figured in the evolution of private life.

3. The end of World War II brought a baby boom to many countries, like the US. In 1946, live births in the U.S. surged from 222,721 in January to 339,499 in October. By the end of the 1940s, about 32 million babies were born, compared with 24 million in the 1930s. It was in the 50s when the birthrates dramatically increased. In 1954, annual births first topped four million and did not drop below that figure until 1965, when four out of ten Americans were under the age of twenty, cited in figures in Jones $(2006,102-107)$.

4. When the war ended in 1945 , millions of veterans returned home and were forced to re-integrate into civilian life. than only looking at a building independent of the people and events that occurred there, we take into account personal experiences and interactions with the physical structure. Hence, the way we conceptualize the domestic life will be recast.

This study will be carried out in the style of the more recent analyses which utilize oral history methods (1) and narrative studies. By focusing on the families' individual experiences, the changing role of family domestic life and interior design will be analyzed within the social context. The use of the oral history method in this study can help to illuminate the historical period and the individual's domestic experience with the changing of space. This method is also appropriate for domestic studies since it uses personal stories, addresses subjectivity, and preserves people's lives by utilizing their memories (2).

Before discussing domestic life in Gainesville, FL throughout the Miller House by focusing subjectivity, it is crucial to understand the architectural atmosphere and region in postwar era.

\section{So, what then does "housing" mean to Americans in the 1950s?}

The postwar era began in the late 1940s, a time of transition and new beginnings for architecture as well as every other field. America was ready to rebuild and reconstruct life. Firstly, after the war, family patterns changed. Marriage rates and birth rates increased (3). One of the most crucial sociological changes is that women returned to the home after men returned from war (4). Thus, a sudden demand for new housing arose and industry refocused on civilian needs. Especially, the 1950s witnessed a great expansion of housing. Virtually everything that occurred in America residential architecture and design in the immediate postwar years came to fruition in the 1950s. The result was the mass production of standardized middle-class dwelling in huge suburban tracts. Despite the generation of numerous housing types such as house trailing and mobile homes, splitlevels houses etc., the ranch house emerged as a popular icon of the 1950s. Its low cost and simplicity made the ranch house the ideal starter home, and the prosperity of the fifties allowed more and more Americans to become first-time homeowners. The ranch house was basically a one-story rectangle, with the long side facing the street. It had a carport, a kind of open and roofed garage at one end which served to shelter the automobiles. They also had a front entry, but no front porches- once an opening and welcoming component of American house design (Young, 2004).

When we look at Florida after World War II, we can see that population growth and an expanding economy were transforming the landscape of the Sunshine State. Hundreds of thousands of people settled in Florida and sought housing, particularly new homes in the suburban areas of the state's metropolitan regions. One of the most noteworthy of these cities is Gainesville.

Gainesville was chosen as the context of this study because it is unique and because there is not a great deal of research on the city in existence, unlike similar locales in Miami or Sarasota. Although Gainesville is a small town different from many other cities that we might consider, we can still follow the traces of modern domestic approaches to houses within the city because it developed its own modern style. Here, domestic architecture took forms which were different from those in any other state because Florida has the unique conditions of high temperatures, high humidity, and a vast insect population. Each region of the state demonstrates either 
a unique pattern of design or a cohesive architectural approach which can reveal differences amongst domestic spaces.

The corresponding term used for "ranch house" in Florida is tropical home. Characteristic elements of such houses' architectural styles include porches for living and sleeping, walled patios, terraces, balconies, habitable roof decks, loggias, verandas and exterior stairways. In providing shelter and protection, Florida architects employed raised floors, overhanging eaves and cross ventilation, while experimenting with continuities in indoor and outdoor spaces. So, in 1950s, the Miller house in Gainesville that will be examined as the case study in this paper is an example of a tropical house/ ranch house.

Here, a crucial controversy lies in the fact that these ranch houses are being demonstrated and represented as an upper-class or even much wealthier homes, having a domestic lifestyle described as a "dream life". After WWII, everyone, it seemed, wanted a part of postwar version of the American Dream. In publications during the postwar era a complete and happy life was often described as including marriage and life that revolves around the family. In general women found fulfillment in bearing children, and regarded it as the highest form of happiness. (Mintz and Kellogg, 1988) After the war, American women had a tendency to marry and start to a family instead of receiving education and beginning careers. These alterations affected their perspective regarding the home and domestic life (Figure 1).

The 1950s era was perhaps more modern than any other era because after the war people were starting new life styles. They were searching for a new interior space in terms of its usefulness, comfort, and beauty. The war had created an atmosphere that was favorable to modern architecture due to the need for technological innovations, which translated into a surplus of such advancements at home. After WWII the television and new appliances like dryers and dishwashers represented upward mobility for the middle class and allowed people to accomplish household tasks much more quickly and efficiently than ever before (Figure 2). Decreases in the domestic workload

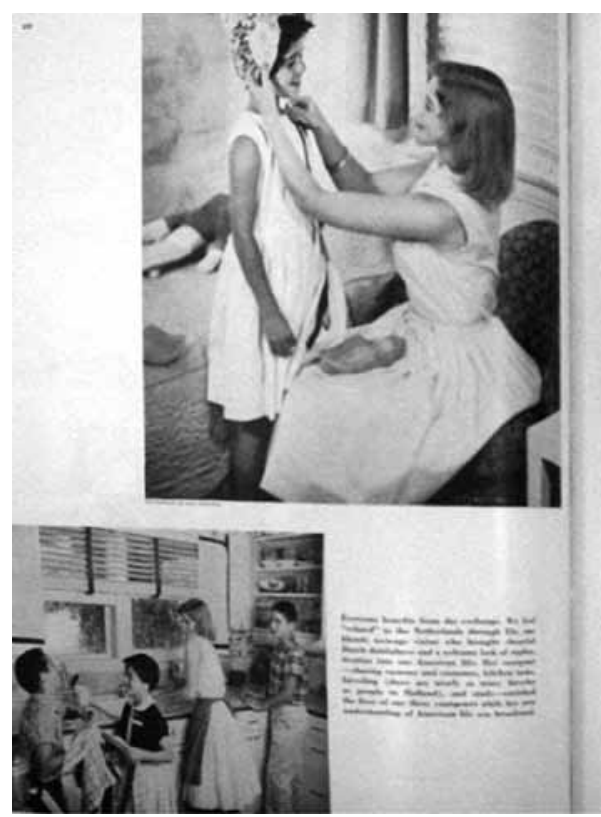

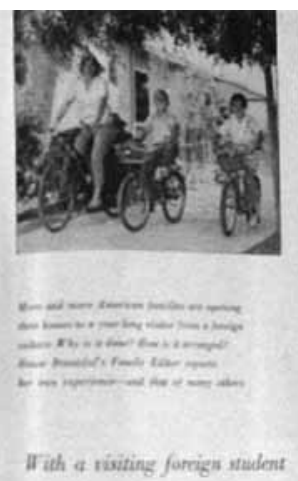

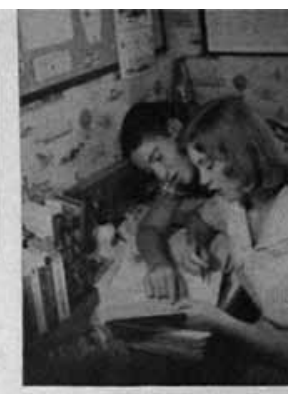

"Cultural Exchange" can begin at home -your home
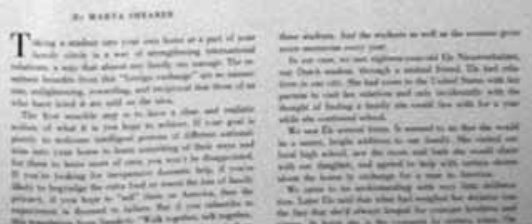

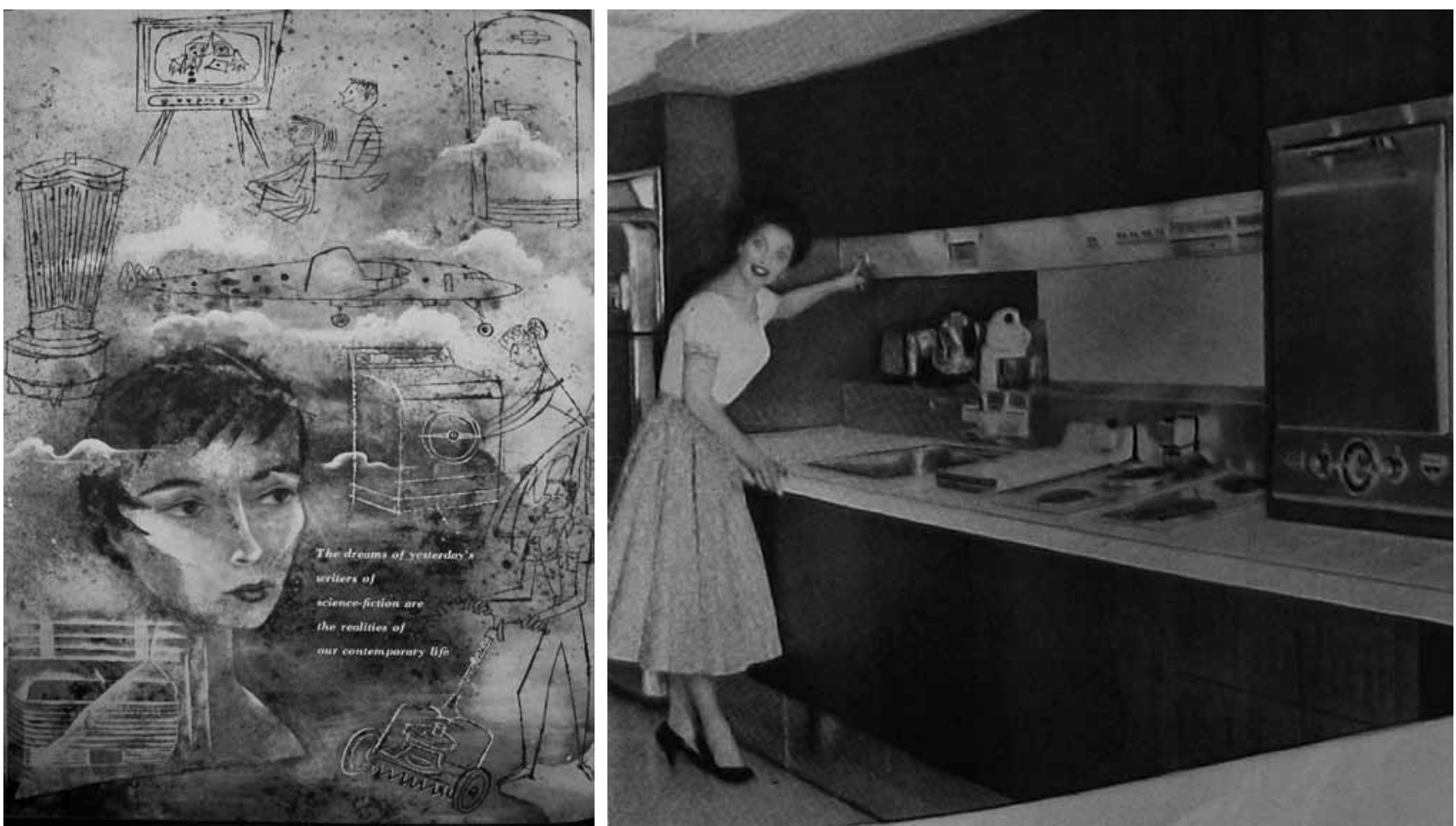

Figure 2. The dreams of a housewife in the 1950s (Barry, 1955, 62).

Figure 3. Media reinforced the ideal image of family by showing housewives as happy and elegant. (Barry, 1955, 99).
5. Harris's grandparents purchased their first house in Southern California's San Fernando Valley in 1955, and it was the home they occupied for the rest of their lives. led to an increase in leisure time, meaning that the home became a place for relaxation as well as domestic chores.

The 1950s period was a time when people thought about change optimistically. This is due in large part to the way that the media created its own domesticity instead of showing the real middle class domestic life. Media reinforced the ideal image of family by showing the reunited families of war veterans and women happily staying at home all together. This created a new image and perception of housewives as happy and elegant people who "don elegant dresses, high heels, jewelry and smile as they dust and vacuum." (Young, 2004) (Figure 3) Most Americans of the postwar period could not afford them. However, the ideals were presented in popular publications and the television. As Dianne Harris (2013) said, during the postwar era, "like thousands of other Americans, my grandparents read newspaper and magazine articles that focused on house design and interior decoration; they watched television shows that focused on domestic life..." (Harris, 2013)(5).

However, all these alterations in the media were not easily accepted by people in reality. Looking at the real homeowner's perspective reveals that our perceptions have the potential to be totally different. Many were reluctant to change their habits, tastes, and values. Because people were socially more conservative because tradition was still a powerful influence on society. Howey (1995), in his book admits that, "there was, and still is, considerable fear and dislike of drastic innovations devoid of obvious connection to the past."

With these contextual clues in mind this study aims to reveal to what extent the real lifestyles of the homeowners were influenced by those "ideal homes" described in the publications. A real homeowner was chosen as the subject of a case study, the Miller house, in order to fully comprehend what 
kind of changes he and his family accepted and how they adjusted their domestic lives. In this respect, the writer uses interview conversations to speak about architectural practice in the space by using the words of Paul Miller.

\section{CASE STUDY HOUSE: THE MILLER HOUSE}

To put it simply, home is what you make it. The house where we spend most of our daily lives is more than just a building. Regardless of the size or style of the house, the home is where we perform the basic tasks of our everyday lives with our family, friends, and neighbors. This is what forms the fundamental basis of our domestic lives.

We use studies of domestic life, among other things, to analyze the evolution of modernism because the domestic sphere is where these changes are readily observable. When performing an analysis of domestic life, it is vital to consider a subjective approach because we must observe the idea of "independent thinking" (Jackson, 1994). Each person retains this quality of thought by having his or her own modern domestic approach to his or her home. As asserted by Susan Kent, "architecture does not determine behavior" (Kent, 1990). Therefore, if we can look through the eyes of home owners and consider their personal tastes and life styles we can better understand how they constructed their own "inner world" in their houses (Attfield, 2002). We can then not only get a closer sense of the general trends from their time but also discover and preserve the nuances of such patterns.

The Miller house (6) is ideal for examining the postwar middle-class house because the homeowner changed some items of the house by basing them on modern developments in Gainesville. We can easily observe how modernism was embraced or discarded by the Millers and how their personal identities interacted with the contemporary concepts of design. We may also come to capture concepts that are unique to their particular era and region by depicting social and cultural incentives.

\section{The Background of the Millers}

6. The Miller house was examined in this study because Paul Miller is a "modernthinking personality" to tell us about his house and his domestic life during 1950s. Even though we have contacted many families who lived in 1950s, only Paul Miller accepted to meet us every weekend and to tell about his story. We were also introduced second owner of the house which provided us to get new opportunities for having more information about the house. In addition to these, the significance of this study comes from the fact that here the house is analyzed with the homeowner himself/herself who has been living in, not just the 'house/building' itself.

7. Paul Miller was born in 1947 and currently resides in Gainesville. He was kind enough to share his memories of the time during which he and his family lived in the house. That we are able to know so much about the domestic life of the Miller is thanks to Paul Miller's archive.

8. Interview with Paul Miller. 08.19.2010. 06:22 PM.
The Miller house was owned and occupied by Howard Miller and his wife, Grace Miller, until the 1990s. Howard Miller was a professor at the University of Florida, Grace was a homemaker and they had two children, Paul and Rosemary. According to Paul Miller (7), Howard grew up on a farm in Tennessee but he did not want to be a farmer. He left home to complete his education and was a successful student. In 1947, he was offered a job at the University of Florida where he continued to be a successful academic. He worked to support his family but yet, the university constituted a large part of his social life. Grace Miller was a busy woman with household chores, service organizations, and church. She took care of her children and often did volunteer works at the hospital and woman's club. She never had a paying job but she lived the life of a fulltime employee.

Howard and his wife both sought a new and different domestic life and hoped to achieve this through a new house. With his job security, Howard was able to borrow money from the bank and finally he and his wife could manifest this notion. As Paul Miller said, "My father dreamed of more material things, and my mother and he felt confident enough to fulfill their dream" (8). 
Figure 4. This page from a 1953 edition of House Beautiful magazine captures the desire of the Millers to have a house as well as its prevalence in the media. "I dreamed of a new house last night" (Barry, 1953, 29).
9. The postwar economic boom and the federal financing and mortgage insurance programs made the housing available to millions of first-time homeowners. (Harris, 2013).

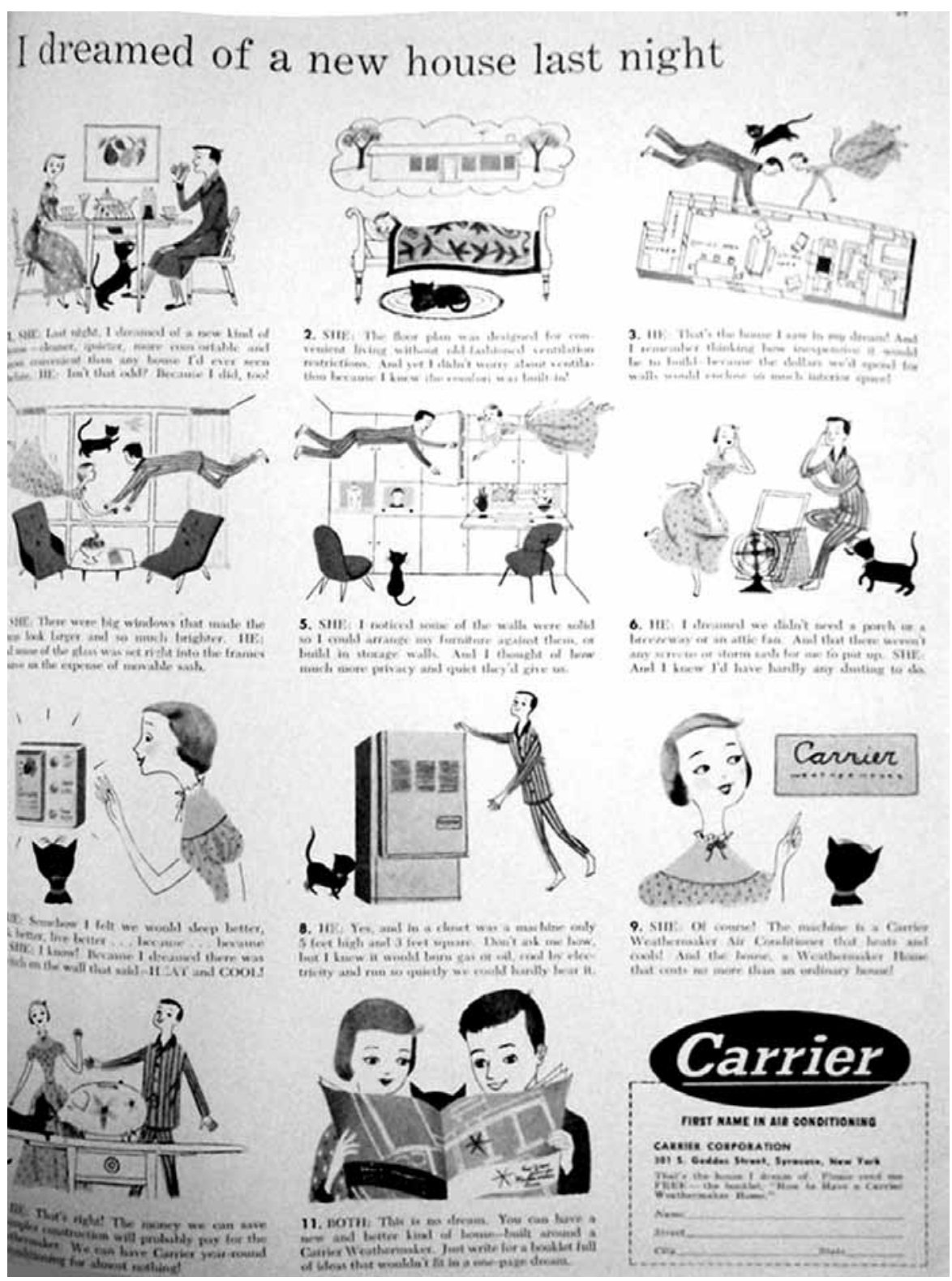

Borrowing money (9) to build the house was slightly unnerving for the Millers as a single-income family, but it was also exciting. It meant that they could live in a new house that embodied the beginning of their "dream" for a new life. Being open minded and taking on the debt resulted in a house that displayed their upward mobility and allowed the family to experience a variety of social activities, freedom for individual fulfillment and pride in their home. People in general started borrowing money from the bank after the war for similar reasons; everyone desired to own a house that they could "show off" to other people. Before the war, construction was more limited and stagnant so people had less control, but afterwards this was not the case. This resulted in an abundance of individuality amongst new houses as people began to design their home in accordance with personal tastes (Figure 4). 


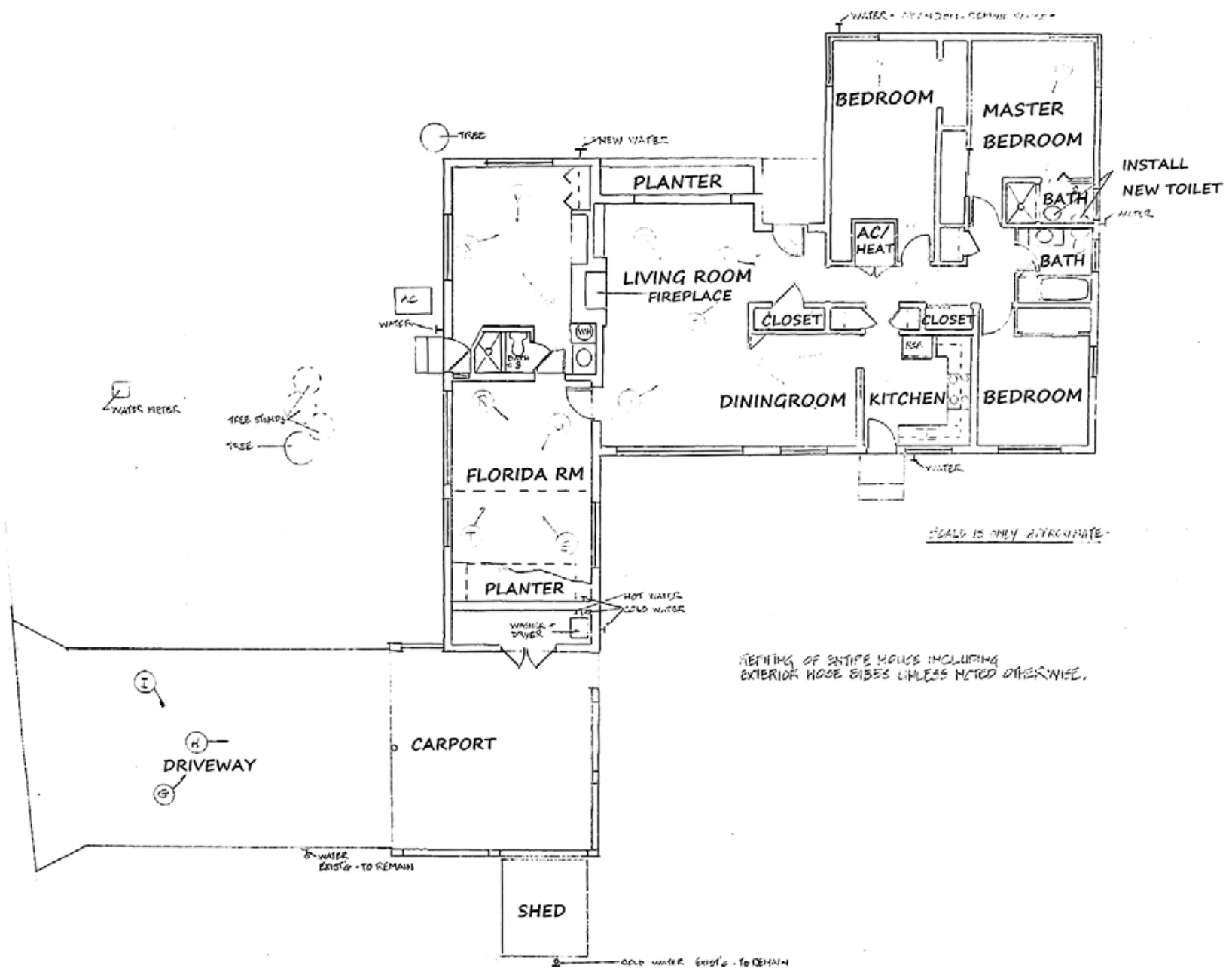

Figure 5. The Miller House, Layout. (Drawn by Barbara Pietsch in 2007, Barbara Pietsch Photo Album).

Figure 6. The porch which later became the Florida room-behind Paul, Rosemary and Henry Bankson who was their grandfather.

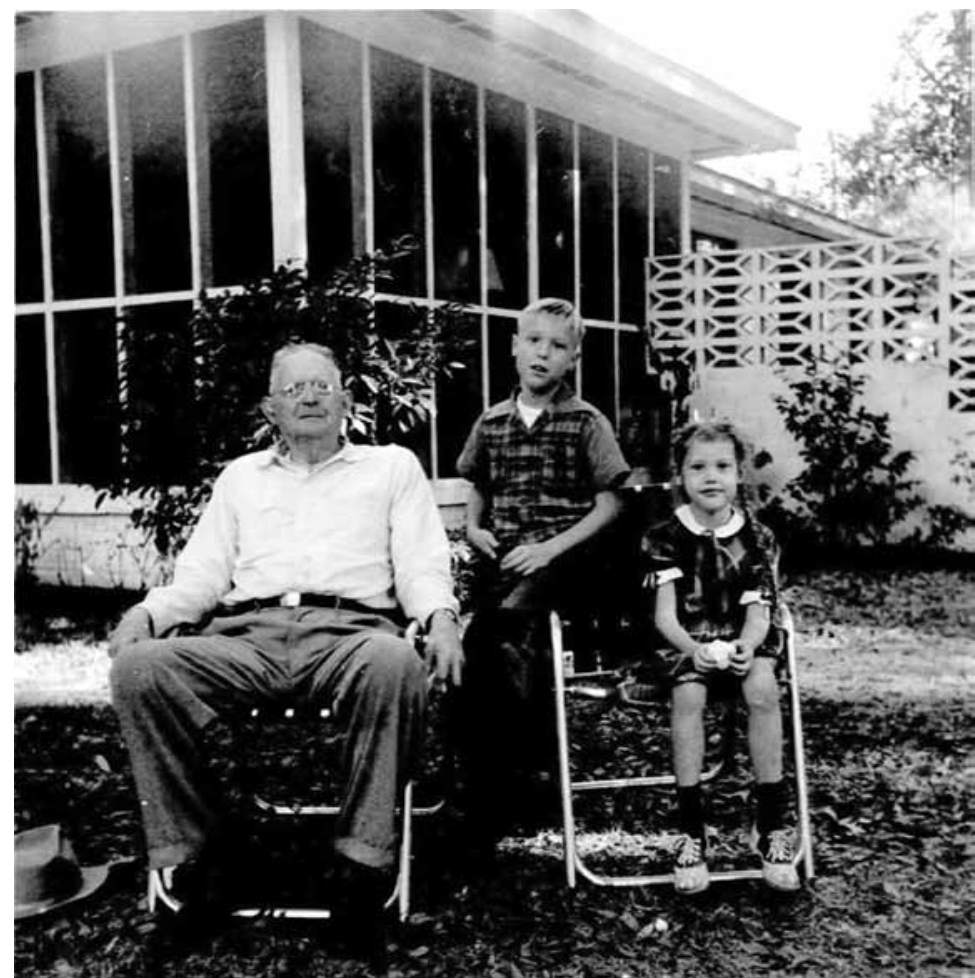
1958. (from Paul Miller archive). 
The Millers, following suit with their contemporaries, hired a builder and construction began in 1950, which was so common in that era. The construction industry had significantly developed by this time making construction more affordable and quicker than ever before and the Miller house was erected promptly in six months time. Although Howard took technical recommendations from the builder he was the primary designer of the entire structure. His taste was further reflected in the home because with the money he was lent from the bank he had the flexibility to indulge in his personal taste while selecting the furnishings. They saved up money for ten years after the construction was completed in order to convert sections of the house into new rooms and to continue to buy new furnishings. The common plan in the 1950s was the L-shaped plan and that was the Miller's original layout until Howard made his alterations (Figure $5)$.

At one point he converted the garage into an extra bedroom, which at times they rented to local college students. At another point he also renovated the porch, turning it into a family room - a Florida room as Paul says- for use as the primary common space (Figure 6). Other smaller structural changes were made and will be discussed in detail.

\section{APPROACH TO ANALYSIS OF THE MILLER HOUSE}

Usually when we try to perform research regarding architecture, we only examine the plan, section or façade of the building. This produces a good general understanding of the subject but it is objective and distant. As previously mentioned, I would like to gain a closer understanding of not only the layout, but also how people used each space. I would like to avoid generalizing an entire time period into a specific set of concepts and instead develop an intimate, detailed knowledge of a single representative family. As Lesley Jackson asserts, "variety and delight were identified as the two keys characteristics of domestic architecture in the USA by the mid1950s." (Jackson, 1994) If we want to capture the "variety" and "delight" of the era then it will not serve us to make generalizations. The Miller house, a typical 1950s' middle-class house in Gainesville, was conceptualized by the homeowner rather than an architect or a builder, which makes it an excellent specimen for this study because it is truly a personal space (Figure 7-8).

This study follows from the assertions of Attfield: "the domestic interior is posited here as a cultural symptom of the dynamic process of social identity formation rather than the way it is usually discussed - as a question of design form or style." (Attfield, 2002) Obviously, we cannot understand the modern building by just looking at the plan or elevation because the inside and outside cannot be separated from each other. A plan may show us what these components look like at a single point in time, but not how they are being used, and certainly not how that use affects the evolution of what the space looks like over time.

The analysis of the Miller house will reflect Paul Miller's recollections of his experience in the house. The primary information comes from interviews with Paul while necessary attention was given to other objective sources. Paul remained a valuable resource throughout the study and writing process. His recollections are not scientific or analytical but personal, like he is describing characters from a story. In order to reflect the intimacy and subjectivity of the data collection process, the discourse of his experience 

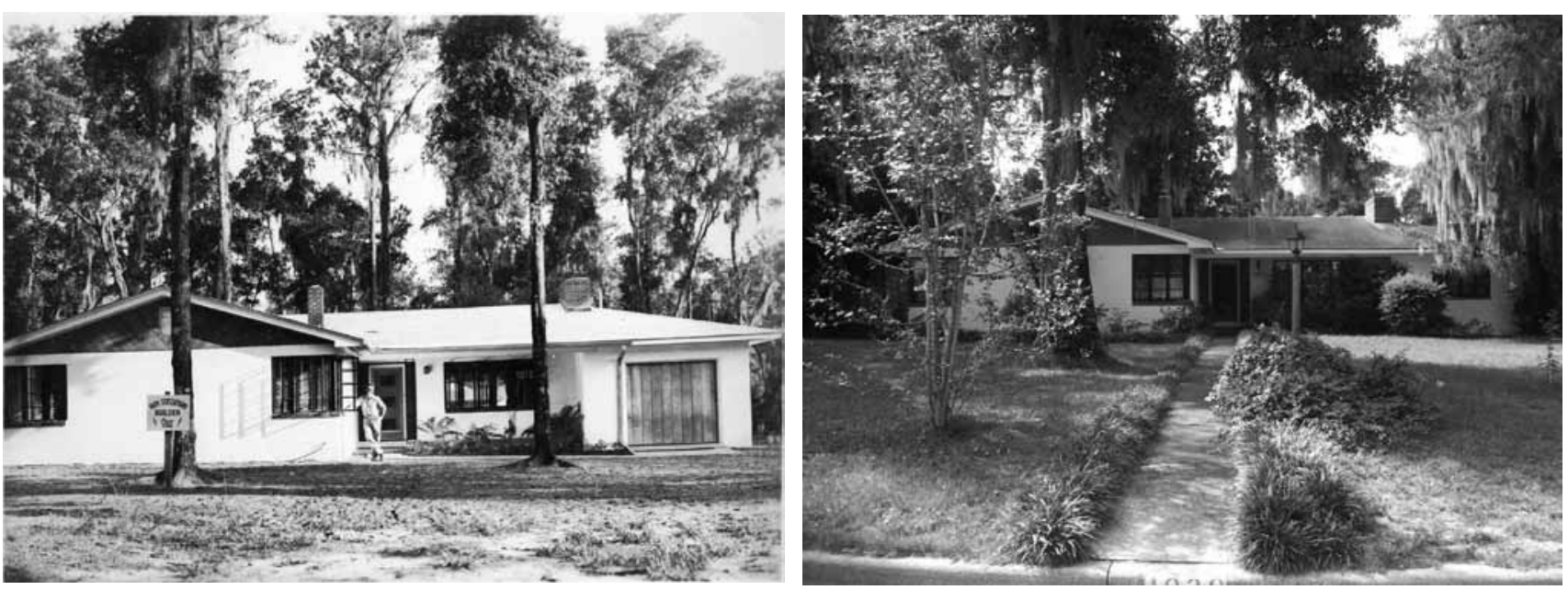

Figure 7. Front view of the Miller House with Ray Tassinari, builder, 1950. (from Paul Miller archive) Howard took pride in the appearance of the exterior, especially the front door, which he designed to be the focal point of the façade. It says to passers-by that this is a "nice house." Howard also designed outside planters for special ornamental plants and had the builder incorporate them into the construction in both the front and back of the house.

Figure 8. Front view of the Miller House. (Taken by Barbara Pietsch in 2007). will be structured very similarly to a biographical narrative with my own commentary and analysis. This method will underscore the nuances of the family's individual experience, which in turn reveals more about the evolution of the design. Since making some generalizations is necessary to consolidating large amounts of data into workable information, this method is desirable because it does not obscure the reality of individual lives. In this paper, the form of narration also provides to tell us the postwar period's social and cultural incentives in a specific region, Gainesville, Florida.

What follows is an account of a typical day in the life of the Miller family during the 1950s, which has been superimposed with my analysis.

\section{“USAGE" IN 1950}

7:00 AM

A typical day for the Miller family began at 7:00 AM except for Grace, who woke up at 6:45 AM to dress and prepare the breakfast. Howard and Grace slept in the master bedroom, and Rosemary and Paul had their own separate bedrooms. Howard, as the head of the family, used the smallest bathroom of the master bedroom to prepare for the rest of the day. The children and Grace shared the much larger common bathroom. Breakfast was served at 7:30 AM in the dining room and usually consisted of eggs, bacon, and toast but on Saturdays and Sundays Howard would prepare pancakes for the family. Breakfast was very informal; everyone would walk in at their own convenience and eat quickly. Howard left for work in the family car at 7:45 AM and the children would walk to school, which commenced at 8:00 AM.

8:00 AM

After the children departed Grace would begin the household chores. Before it was renovated to be a spare bedroom, the garage housed the Millers' water heater and was the primary location for washing laundry because it was a semi-open space directly connected to the outside where the clothes were taken to dry on a clothesline. They got a dryer in the 1960s, but Grace seldom used it. The garage was not used as common space by the whole family, and it was separate from the main house with its own entrance, which is why it was available to convert into a new room. After they converted it, Paul used it as a bedroom during high school and when he moved out it was rented to college students. 
10. Interview with Ron Haase. 13:00 PM

11. Interview with Paul Miller. 08.19.2010. 06:22 PM

12. Interview with Paul Miller. 08.22.2010. 04:10 PM.
Figure 9. The backyard of Miller House in 1961 (from Paul Miller archive) and 2007 (Photo by Barbara Pietsch in 2007).
Grace was dedicated to the cleanliness of her home. She scrubbed the sinks, toilets, bathtubs every single day. She vacuumed, mended clothing, and did laundry, dishes and several other tasks. She was also the guardian of the family finances. However she was not the sole caretaker of the family home. Howard was responsible for repairing things around the house, repainting surfaces, scrubbing the wood flooring, caring for the rose garden, and drying the dishes for Grace after dinner. As the children grew older they too became responsible for chores. Paul would mow the lawn and Rosemary helped her mother.

10:00 AM

After some of her chores had been completed, Grace would occasionally visit with some of her neighbors at around 10:00 AM over a cup of coffee. There was trust and friendship among the community and so there were no fences between the houses. They only used hedges to mark boundaries between backyards. All the neighbors had small pathways leading from their own yards into each others' backyard; which made it even easier for neighbors to socialize. If she wasn't taking care of the house of meeting with neighbors Grace would often have volunteer activities during the morning and afternoon.

Socializing with neighbors was much more common in the 1950's than it is today. Prof. Haase, an active architect, observes that before the 1950s, the front porch was a popular place for the family members to sit and talk to each other or neighbors (10). However, in the 1950s the backyard replaced the front porch as the location for these kinds of activities. The result was that the front porch disappeared or was no longer significant, which may explain why Howard chose the space for renovations. As Paul said, "The backyard was friendly." (11). The outdoors was the popular environment for socializing, at least for a significant period of time prior to television and air conditioning. The backyard was a place where people entertained their neighbors and friends by having barbecues, parties and by playing games. Popular activities for the Millers' neighborhood included basketball and hula-hoops- which were a popular culture sensation in the 1950s (12).

The backyard was also used as utilitarian place for hanging laundry to dry and growing flowers (Figure 9). The picnic table acted as an extension of the kitchen for Grace because it was a pleasant location for food preparation and working out there allowed her to interact with her
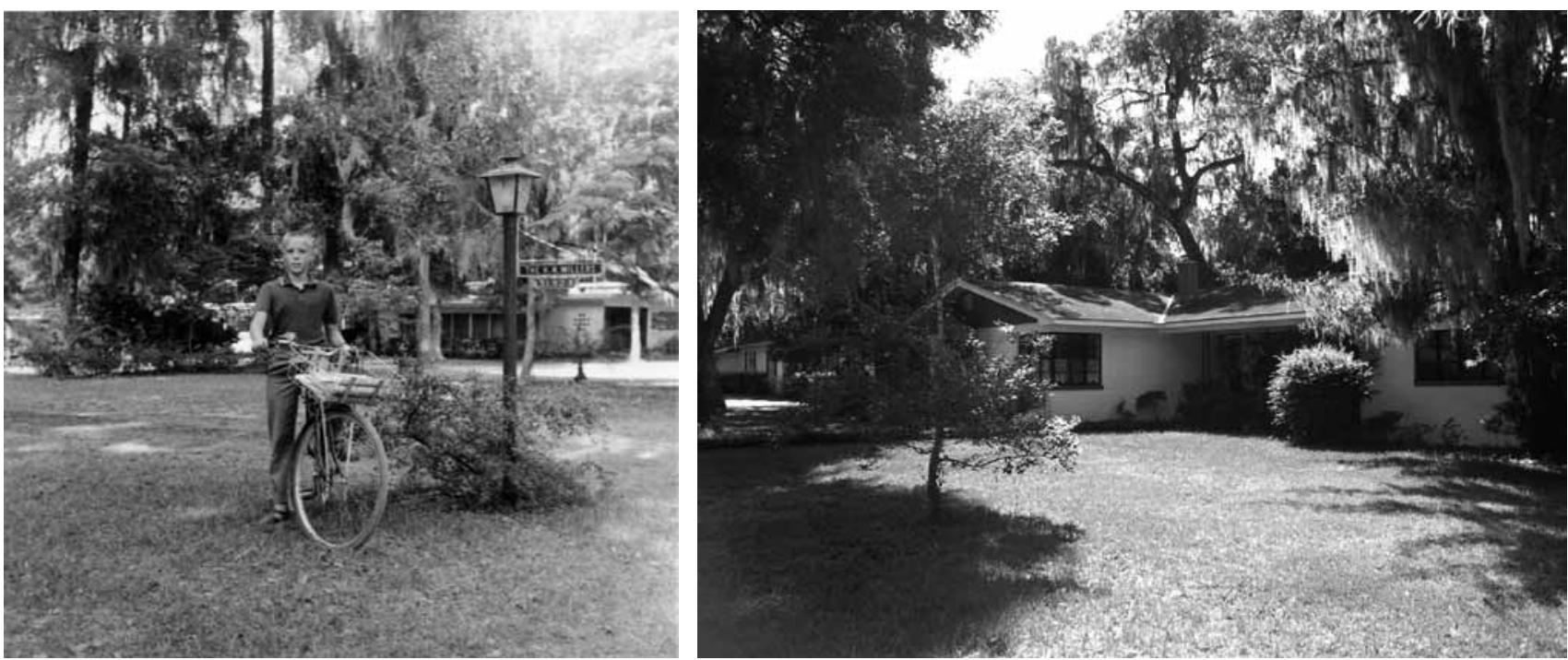
family and neighbors. The home vegetable garden in the backyard became obsolete as all groceries were purchased in grocery stores during the 1950s but besides this change it was a major center of life for the family.

11:00 AM

After some chores or a visit with friends, Grace would go into the kitchen and prepare her husband's lunch which usually consisted of a sandwich or leftovers from the previous evening's dinner. She prepared the meal on the Formica countertops by the sink since they were so simple. Howard only had about 35 minutes for lunch so extravagant meals were not possible. Howard and Rosemary ate their lunches at school in the cafeteria. Lunch was an informal meal for the Millers.

Functionally, in the past, the kitchen was a room of wasted space and unnecessary steps; before running water and electricity became household staple in Gainesville kitchens required a different set-up and much more effort to use. The Miller kitchen was planned for convenience and many activities were conducted there including food preparations as well as both working on chores and socializing; it was where Grace cooked but also where she ironed clothing and sat with Howard for lunch. The kitchen table seated three and would sometimes be the scene of an activity that did not involve food, for example the children would get help from Grace with their homework there. The simple wooden table and basic chairs contributed to the kitchen's informal atmosphere, which contrasted highly with the dining room, a much more formal room. Their kitchen also had many stationary objects: a sink, a counter and a few appliances. The counter was made of wood with a Formica countertop and the cabinets were made of high-quality wood; even today Paul Miller speaks of these with pride. The space was also a very high traffic area and so it had synthetic flooring, which is easier to clean, instead of the wood flooring that could be found in most of the other rooms.

The Miller kitchen represented a transition from the trend of the pre-war era into the post-war era because it had neither a traditional plan nor totally open plan. In the pre-war era, the kitchens of middle class homes were very much like a box with a single door, but later on the trend was that kitchens connected to a number of other different spaces. The Miller kitchen had one door, which was always open and connected it with the dining space, a second door to the hallway, and a third door leading out to the backyard, all of which reflects the open plans that would be popular in the future. There was also a large window above the sink from which Grace could watch her children in the backyard while preparing food or doing dishes. When we look at 1950's journals, the kitchen was inseparable from the living room and they were already idealized as a singular open space. However, unlike the journals suggested, the kitchen and other rooms in the Miller house were still separate spaces (Figure 10). Even though some

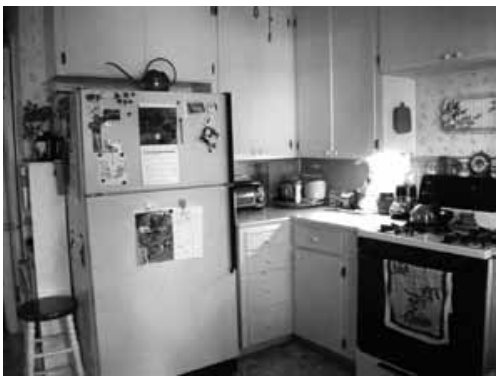
of the kitchen doors were always open, the fact remains that they could and sometimes were closed. A small pantry was situated in the corner of the room that was adjacent to the hallway door but in order to access it, the kitchen had to be closed off from that part of the house. It is the family usage- their desire to keep the space open- that reflects the evolution of the space. Despite the somewhat closed structure, the use of each defined space in this home slowly multiplied until the rooms were more multifunctional than in the past.

Figure 10. Barbara Pietsch's kitchen, 2007. (Photo by Barbara Pietsch in 2007).

Despite the manner in which the Miller's inadvertently reflected the trend of open-planning there were many ways in which their kitchen did not 
reflect the ideal standard of the day. One could observe in the journal House Beautiful the "ideal" kitchen and find that the Millers' room was quite different. In the Florida Park development- the area where the Miller house was built- kitchens were generally small, mostly perhaps due to expenses. Paul expressed multiple times that his family's kitchen was much smaller than was desired. The lack of space in turn led to another discrepancy between the Miller home and popular culture, because they did not have room for the latest appliances.

The Miller family's appliances were limited to a refrigerator and gas oven as well as a toaster and a small electric oven. Some kitchen appliances, like the dishwasher, could not be used in the space due to a lack of access points for plumbing and electricity, a lack of physical room for such large equipment, and also due to their high cost. Many articles and advertisements in House Beautiful journal were written about contemporary kitchens that were convenient and beautiful, but change to this standard was slow in the real American world and this holds true for the Miller kitchen as well. The ideal American home at the time included many changes to traditional standards but the actuality of change was uneven because people's tastes, desires and feelings are the most powerful factor that determines their use of a space.

12:00 PM

Howard would return to the home at lunch time to enjoy his wife's cooking and then immediately return to work. Grace would continue to take care of her household chores after lunch and well into the afternoon, unless she had a function or volunteer work scheduled for the day. Rosemary and Paul would return to the house after school in the afternoon at about 3:30 PM, change their clothes and head back outside to play with neighboring children.

6:00 PM

Dinner was served everyday at 6:00 PM sharp but Grace would start calling out into the streets for her children at 5:45 PM everyone would wash up and sit down to a formal family meal in the dining room, with Howard, who would just be arriving home. Howard sat at the head of the table, Grace at the opposite end and the children on either side in between. The meal was always very formal and often dictated by which day of the week it was; for example, they always ate fish on Fridays. The typical dinner consisted of many courses, stating with a salad and bread or soup and then the main entrée. Meat was present at every meal, particularly red meat and they always had a diversity in the selection of food. On occasion they would go to a restaurant but this was not an everyday occurrence.

The simplified modern combination of living-dining room and kitchen was to come in the future but in this house, this idea can not be seen totally because even though their dining room was a part of the living room, the kitchen remained separate. In the early 1950's the Millers were in debt to the bank because of the purchasing of the house and so they had a limited ability to buy a large amount of furniture. Their dining room only included one dining table which sat four people and could be extended to accommodate eight to ten people. This table was used informally at breakfast. For dinner and special occasions, the dining room table was a more formal setting. Better dishes were used and more complimentary items such as butter, cream, sugar, syrup, lemons etc. were put on the table. Later on, when their debt had been reduced, Howard built an extension between the dining and living rooms to house and displayed the 

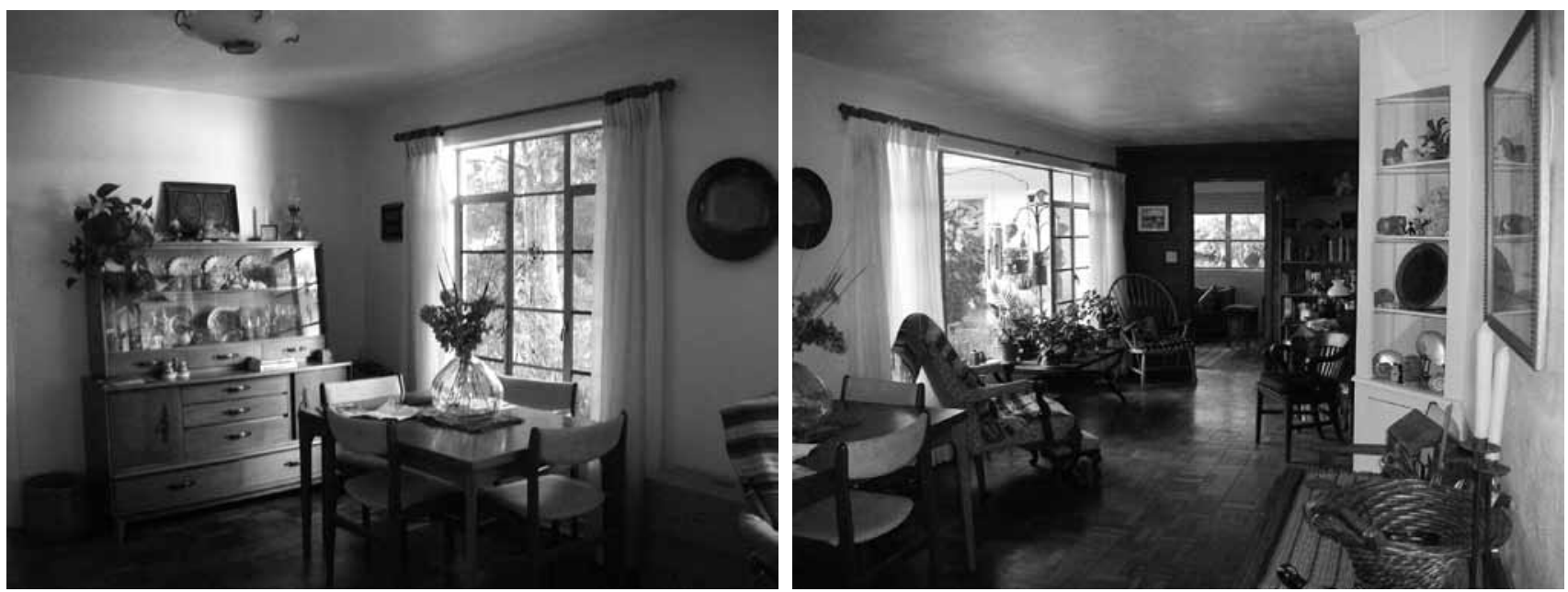

Figure 11. Dining room and living room come together. (Photo by Barbara Pietsch in 2007). family china, a great example of how the family's personality altered the architecture of the home (Figure 11).

7:00 PM

After dinner, sometimes, Howard would go back to work for a few hours and Grace would wash the dishes, do some sewing and mending in the living room, and finally take care of the book-keeping or write a few letters. If Howard did not return to work at night he would work in the living room reading, writing letters, sometimes grading papers or listening to the news on the radio.

The Miller's living room was a kind of radical space for the family because it experienced the most use and the most change over time. Early on, the living room was the most important room for gathering. They had a minimalist approach to furniture; they did not cover their hard-wood floors or paint over their wooden doors. Instead of covering the materials they showed off the natural state of them. This space was much more multifunctional than any other space and was used not only as a sitting place but also for studying, sewing, reading and so on. It was also the room that had the most windows. In 1950's a popular notion was that natural light and visibility were desirable attributes within a space. Technology had advanced to a point by this time where it was possible for the Miller's to have large windows in their living room and even corner windows in all of the bedrooms. The living room furniture was not complicated; there was one fireplace and some furniture such as a couch, some bookshelves, four chairs, a coffee table and a piano but in late the 1950s a TV and a stereo were added.

Furniture had a symbolic meaning as well as a utilitarian function. Some new furniture, electronic devices, and other valuable things like pianos and bookshelves appeared to express the status of the homeowner. Judith Attfield, a British academic, summarizes the situation best: "It is clear that while furniture and money were in short supply in the early 1950s, pride and polish were extremely important." (Attfield, 2002) For instance, according to Paul, Howard Miller was extremely proud of his bookshelves and fireplace in the living room as well as having children that play the piano.

The furniture of the living room was originally arranged around the fireplace, which was made of pink brick, so that it would be the very first 

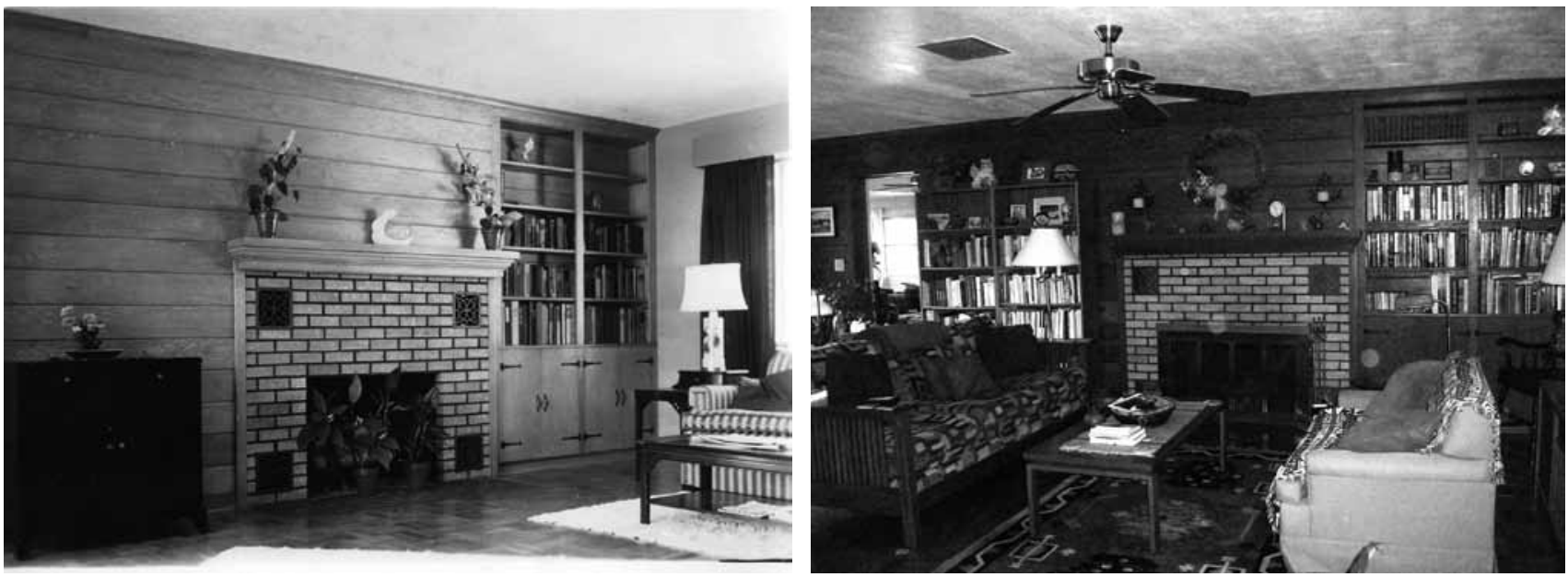

Figure 12. Living Room, 1955. (Paul Miller, Family Photo Album. 11.11.2010).

Figure 13. Living Room, 1955. (Photo by Barbara Pietsch in 2007).
13. Interview with Paul Miller. 08.19.2010. 06:22 PM. thing a person would see upon entering the room. The furniture was also arranged in a way that made movement in the space more efficient. For example, the bookshelves, being so tall, were pushed against the wall beside the fireplace and the couch sat against an adjacent wall with the coffee table directly in front of it so that Howard Miller could access his books, work on the couch and admire his fireplace with ease. Howard used a small radio that was inside the lower book cabinet to listen to football games but it was not common for Howard to use the radio for entertainment, as he felt his mind should be engaged in intellectual pursuits.

The fireplace always has had a special meaning in modern architecture. In Florida, it was less useful than in northern regions because of the weather conditions, so instead of being a functional part of a space it had a more special or spiritual meaning. It was considered aesthetically pleasing in the living room despite the fact that there were more efficient heating devices available. The Miller family preferred to use the central heating system in their home, while, as Paul Miller said, "the fire place was used to cook popcorn, sometimes." (13). Rather than a utilitarian purpose, it acted as a status symbol for its owner (Figure 12 -13). The bookshelves and piano were also symbols in the space; they showed off Howard's status as a well-educated man with well-educated children. It is sometimes difficult to reconcile aesthetics with practicality. Even when we do consider a homeowner subjectively, it is not always easy to distinguish between what is done for pleasure and what is merely ostentation.

As architect Parker said,

I confess a strong liking for a fireplace in a home. I realize they are inefficient that there are better ways of securing heats. However, no one will ever persuade me that a fireplace is not a wonderful thing in a home. I prefer a fire burning in the heart of a house in a masonry wall. Is there in our instincts a strange, subconscious recurrence to a primitive past when we look at or feel the warmth of a fire? (Parker, 1965)

Howard's trinity- bookshelves, fireplace and couch- of furniture was his area and the dominant area of the room. On the contrary, Grace used the opposite end of the couch and her table next to the front door. The children did large homework projects that required Howard's help in the middle of the living room. The children practiced the piano after school or in the early morning when Howard was not in the living room. His dream for the 
living room was that it would be a place for reading and children playing Mozart.

When a television was introduced into the room some of the other furniture was reoriented. Howard did not want to give up his personal habits. His couch, bookshelves and fireplace had a strong enough functional and emotional relationship for him that even TV could not separate them. Furthermore the couch itself was a symbol of financial stability and yet another source of family pride which made it that much more pivotal to the arrangement of the room. When the Miller family bought their television it was placed in view of the couch area, the dominant section of the room, and then the rest of the room was oriented around the new technology instead of the fireplace. The children spent more time on the floor in front of the TV rather than in their rooms or outside. The other furniture, the chairs, Grace's desk and sewing machine all changed positions in order to face the screen. Even though it became more popular than the fireplace it did not become an object of ostentatious pride for the Miller's because they were the last of their neighborhood to acquire the new technology.

After television came into the house in the late 1950's family domestic life changed. For example, before television the family would visit neighbors after dinner or go on walks outdoors but after, they preferred to stay at home and watch television programs instead. Additionally, before television Howard would return to work at night but after he would quit working after dinner to watch the news. The family became much more isolated from their neighbors and everyone's minds and ideals changed. With this great shift in domestic family life there also came notable transformations of the interior design.

In the early 1960's the TV was moved into the Florida room. During our interview, Paul made it clear that the Florida room was one of the most desirable components of the household. The Florida room was made from the old porch and was like many built at that time. Howard had a unique

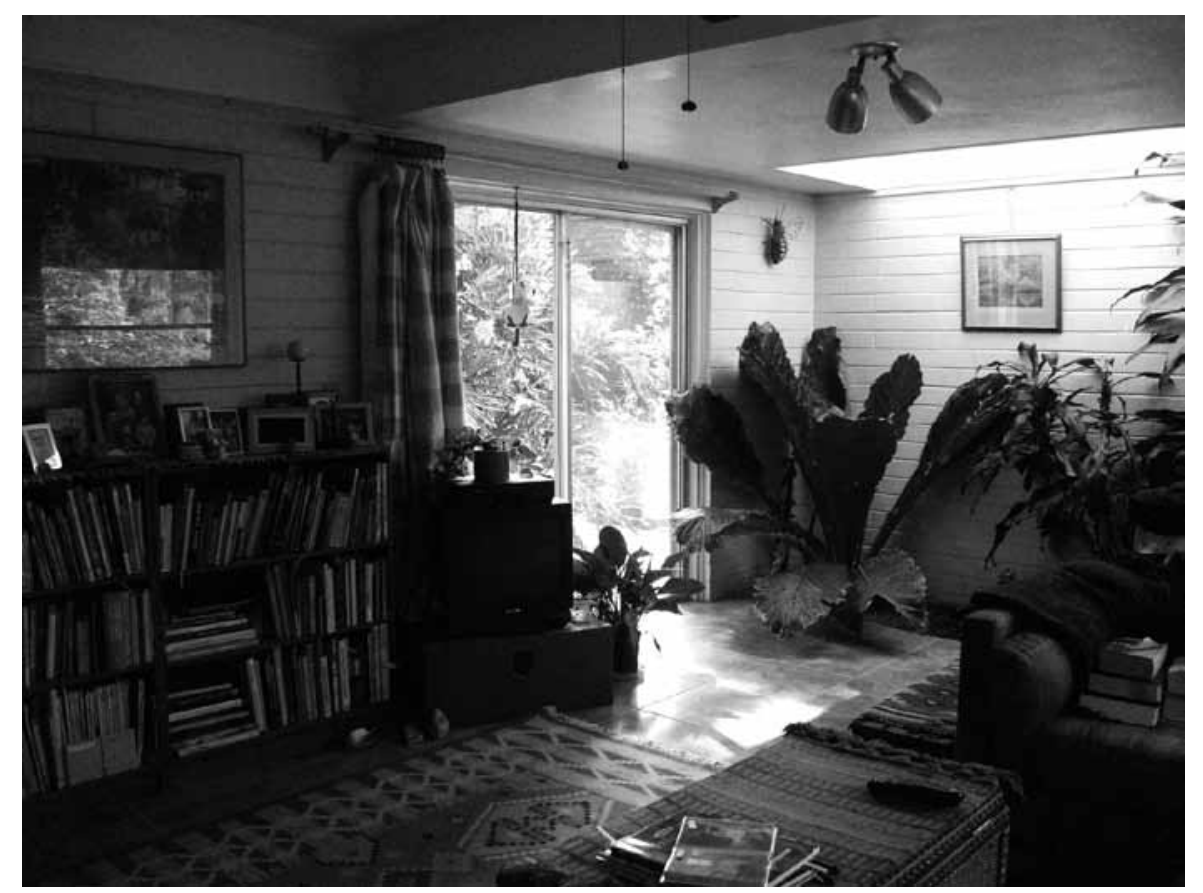


stone waterfall that he made from natural rocks and a planter that he filled with unique ornamental plants. The rest of the Florida room had common living room furnishings, the most noteworthy of which is the television that they moved from the original living room. They even purchased a new couch for the space. The Florida room then became used as a living room and the original living room became a much more formal space where the family would entertain guests (Figure 14).

The Miller family responded to new appliances and developments in their house in a different way from their neighbors. The family used all new things step by step in their home according to their social and economic conditions. In the early 1960s, it was common to add more living space onto a house. The Millers reflected this trend with their own personality by adding the family room with the unusual waterfall and planter.

Another big change to the house that somewhat parallels the television is the introduction of the air conditioner into the house; it made life more pleasant and it caused many changes to the home both physically and socially. Before air conditioning an attic fan system pulled in outside air and evacuated it through the vents. They kept windows open all the time to circulate the air and windows had to face one another to maximize the movement. Then, when they got the air conditioner, they had to put holes in the ceiling for their vents that were connected to the air conditioner by way of duct work. Windows and doors no longer needed to be strategically located to move air around which left even more potential for renovations.

Another change that the air conditioner brought to the home is carpeting. Florida is very hot and humid so before families had climate-controlled homes it would have been very impractical to have carpeted rooms since they would easily grow mold and also hold heat. Tile, terrazzo, or wood flooring would have been preferable because they are easier to keep clean in the heat and provide a cool surface to walk on. Shortly after the Millers put air conditioning in their home they installed carpet in some of their rooms.

The social changes were much more drastic than these though. Families with AC spent more time indoors and did not socialize with their neighbors as often. Paul mentioned that they did not want to go outside and would say, "let's just sit inside." (14). Socializing with neighbors became marginalized. This change in conjunction with television created a society of much more isolated people and also placed more emphasis on the use of the home due to an increased tendency to stay inside.

\section{1:00 PM}

The children would go to their individual rooms after dinner, around 7:30PM, and work on their homework. Grace would check their work and then they would go to bed for the night around 10:30 PM after taking a shower and brushing their teeth. After Howard came back to school around 10:00 PM, he prepared to go to the bed. He would take a shower and brush his teeth. Grace too would wind down for the evening; she might wash the dishes or read books or even mend clothes for her children. By 11:00 PM everyone was in bed.

The house was not only designed with common spaces for dining, living, entertaining and leisure, but also included private rooms for the members of the family. Bedrooms for this family indicated not only sleeping, resting, and studying spaces, but also a clear distinction between the family and its members. The desire for a bedroom was not simply a matter of personal 
Figure 15. Master bedroom (Photo by Barbara Pietsch in 2007). privacy. It demonstrated the growing awareness of the individuality- of a growing personal inner life- and the need to express this individuality in physical ways. All of the bedrooms were located off of the hallway. They were the most private spaces of the home because they were separated from the common spaces and had doors that could be closed. There was a special zoning or separation of private and shared space. The evolution of the communal rooms was much more dramatic than that of the bedrooms, because changes were more often made to spaces that could be shown off and also where the family spent the most time. Gender had a significant impact on the way spaces were designated to family members; we could consider the kitchen as a female place, the couch in the living room as a male place, and the children were divided into a boy's room and a girl's room. The modern idea at the time was that every child should have their own bedroom.

The children's rooms were very simple, containing only the absolutely necessary furniture- a bed, a dresser, a desk and chair- and little adornment, for instance they had hard wood floors and a throw rug but no carpet. There were small rugs in any of the rooms of the entire house because the idea was to show off the details of the materials-even though later on, following the trends of the 1960's, they had nylon carpet installed in living room and new bedroom. Another big change that came with time and new trends was the tendency of the children to spend more time in the living room after the television came into the home whereas before its introduction they spent many hours in their own rooms playing or studying.

Located in between the children's rooms was the master bedroom which was considered a private space for adults (Figure 15). It too was simply furnished and had one bed, a sewing machine cabinet, a make-up table and chair and a large closet. The children were allowed to enter the room when they wanted to play on the big bed and they went there if they experienced a nightmare.

Howard and Grace had a dressing closet in their room as well. At that time it was very important to them to appear well-maintained and the closet was where they stored the many items of adornment that were necessary to maintain the look of formality. Paul said that his father owned at least eight to ten suits. Grace would spend time at her vanity and in her
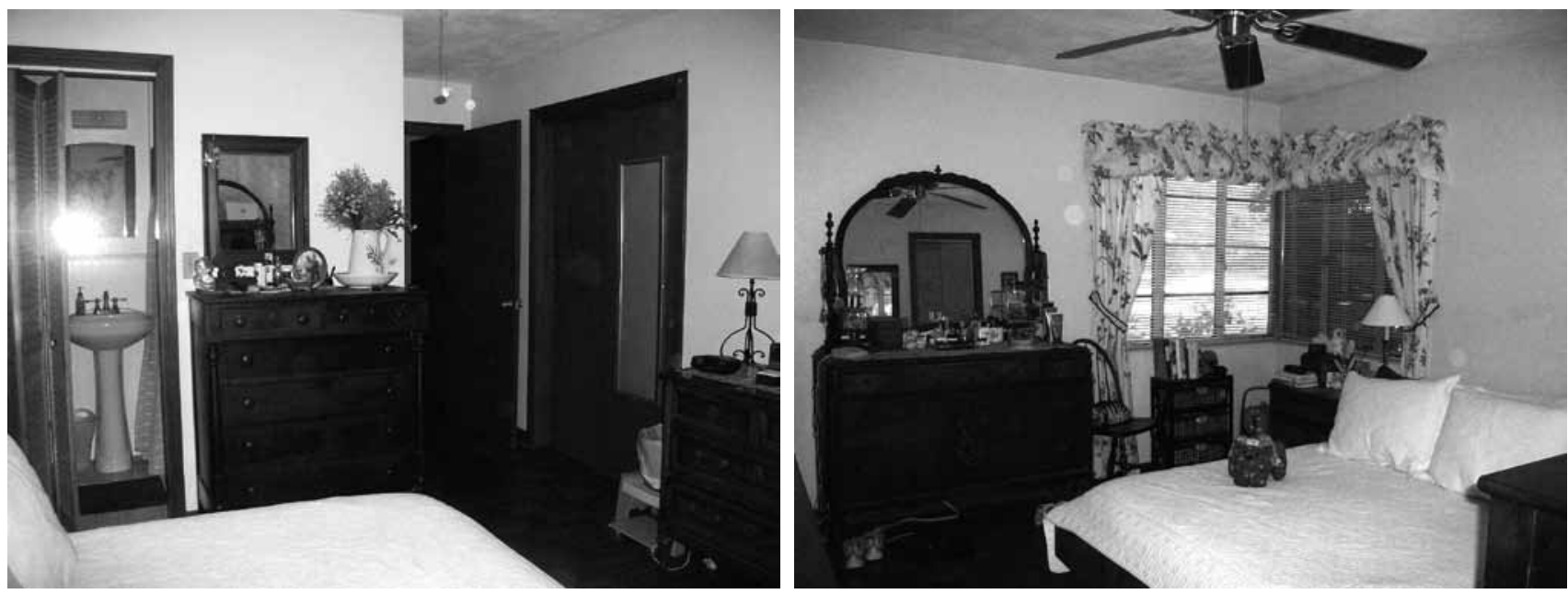


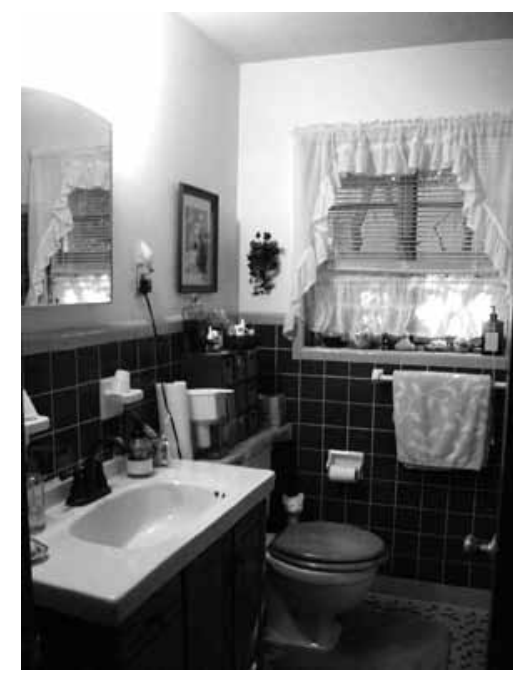

Figure 16. The main bathroom (Photo by Barbara Pietsch in 2007). closet adorning the formal look that was typical of every day life. If the master bathroom was being used, anyone could use the small bathroom. The family all took showers at night so that they could get ready very quickly in the morning. Howard never used the main bathroom (Figure 16). He always used his own bathroom which was small and connected with the master bedroom. After 1960, the house had three bathrooms: the main bathroom, the master bathroom and a new bathroom located in the converted garage.

After they had showered, or finished homework or other evening time tasks the children would be the first to go to bed. Grace made sure they were in bed by 10:30 PM. She and Howard would wind down for a short period of time but by 11:00 PM they were both in bed with the lights out.

\section{CONCLUSION}

Since the 19th century, changes associated with the modern house have been discussed in accordance with various topics. When examined, it can be seen that the vast majority of these conversions focus only on the physical aspects of the buildings. However, unlike tectonic and planimetry methods which discuss merely the "formal approach" of the houses, this study suggests conducting research on modern home by directly utilizing subjective information. It is profoundly believed that evaluating both the subjective and objective information concerning a house should be a basic source for other researchers, who intend to do similar studies in the fields of modern and domestic architecture.

To obtain this subjective information on the house, this paper offers the various historiographies such as oral history method that leads us to understand not only for architectural history but also for depicting a particular period's social and cultural incentives. In that respect, its methodological experimental attitude is worth-trying in architectural history writing as it also breaks down some of the conventions in architectural criticism.

There is evidence of a clear shift both in the nature of debates within architecture and in its relationship with other academic disciplines and their methodologies in recent years.

Architects, architectural theorists and researchers are becoming more receptive to the whole domain of social and cultural theory and this paper supports this development by using oral history and narrative researches in architectural history and domestic studies. In other words, this paper undertakes establishing domestic architecture in a broader social and cultural context, and considering evaluating not only how arguments from social and cultural theory may beging to instruct a discussion about architecture, but also how new methodoligies like oral history and narrative researches may provide a potentially rich field for analysis on architectural research. Textual writing can succesfully work as a medium for criticism on achitectural history whereas the oral history research becomes an alternative method which is critical by shifting storytelling from the historian interviewer to the interviewees. In the research, the subjective documentary provides a critical voice through which is to discuss collaborative architectural practice and the role of personal activities in architectural production. 
In that respect, as given an example in recent studies, oral history and narrative researches were also used in Harris (2013). She analyzed her grandparent's house which served as a leitmotif for her book, just as her memories of her grandparents are tightly coupled to that of their house. Those memories helped her to create the plan of their house that appears in her book, as well as the short stories that appear at the beginnings of the chapters. As American historian White (1998) has asserted, memory is not history; indeed, "history is the enemy of memory." But memories, which are profoundly spatialized to her, provide important portals for asking questions about the past. Harris (2013) said that "while they can mislead as well as lead, I hope that in this instance my memories of a particular house have fruitfully led to the formation of a new perspective on the way we understand the history of postwar housing in the United States."

Methodologically, in this context, what makes this study unique is the emphasis on subjectivity and the presentation of the data in a narrative format to search modern home and domestic architectural studies. The Millers' experiences have been subjectively considered as everyday phenomena in their own context and then revealed in narrative form in order to be an individual study. This archaeological study is based on oral history and narrative research, which utilizes Paul Miller's memories of his house. It is living data that we can interact with and question rather than merely something we must observe. This study presents us a link between objective materials- 1950s journals, books, articles- and the experiences of the homeowner via the comments of the author, and this elicits a better understanding of the house and the period. Most importantly, it highlights the pertinent fact that every family has their own individualistic way of using their home.

Perhaps the most salient aspect of a departure, from the objective approach is that it enables us to get closer to the data, to understand it in a more real way, emotionally, spiritually and so on. The problem that necessitates the subjective approach, however, is not entirely solved by this because living memory- while it does get us closer than the dry accounts provided in books- it is flawed. Living memory is constantly colored by extraneous experience and is not entirely reliable. Paul's perception of his memories, like those of all other people, are continuously developing and changing with time and since this is an expected quality of the subjective approach, it is accounted for during the writing process. There must be an inter-play between the objective and subjective that allows us to become as informed as possible about the subject, but a reliance on either will never make us anything more than observers. By using these research techniques we are able not only able to better understand the reality and individualistic experiences of the Miller house, but also to avoid generalizing the domestic life of the period.

This unique examination gathers rich and meaningful data that may inform future domestic architectural studies and grant insight into how to construct any study. It provides researchers with a key to discovering everyday life and understanding it as a narrative construction, instead of the idealized domestic life presented in journals. It allows new understandings to be sought in an evolutionary way that enables a shift from 'known' information to 'new' viewpoints that otherwise might have been taken for granted. We can consider this a re-conceptualized approach to the examination of the 1950s house because it involves the collection of individualistic experiences via interviewing real people. Hence, this study 
basically aims to generate a new source by means of the personal archives that had never been published before.

Another notable characteristic of this research is the collaboration process between the researcher and homeowner during the writing process, a collective effort that made the construction of the study desirably dynamic. Paul was not only the main actor in the narrative but also played an important role during the writing process. He shared the details of his family's domestic life, but also actively contributed to the article by giving new ideas and editing during the process. This was crucial as it enabled us to reconcile misunderstandings about the many details he provided. Furthermore it allowed him to play an important role by contributing his own ideas. This follows from the idea that professor Wertsch asserted, "As individuals are telling their stories, they are not isolated and independent of their context. On the contrary, it is important to remember that the individual in question is irreducibly connected to her or his social, cultural and institutional setting" (Wertsch, 1991).

All in all, this methodology may continue to prove itself useful in broad array of topics in architecture, and applications continue to become more creative.

Considering specifically the case study of the Miller house, contributions of the domestic changes have been evaluated in space as follows.

During the post-war period, America began to rebuild and reconstruct domestic life, which led to a proliferation of new housing types. These houses along with their photographs and blueprints have been described in many publications in a modern context. Although such publications suggested a modern domestic life by offering new types of plans and modern appliances for usage, the Miller house, seems to represent a transition layout between the trend of the pre-war and post-war eras. For instance, when 1950's journals are examined, the kitchen was inseparable from the living room and they were already idealized as a singular open space. However, the Miller kitchen had neither a traditional plan nor completely open plan. Unlike the journals' suggestions, the kitchen and other rooms in the Miller house were still separate spaces.

Another significant observation is that of the increasing multi-functionality of the used spaces over the years. New appliances - such as TV, air conditioner etc.,- were brought to the home and used to create new functional spaces. The prevalence of these machines as well as their effects on the home can be regarded as a significant representation of the modern domestic life. For instance with the growing popularity of television, family members began to change their sitting positions in the living room so as to see it more easily. However, all of these changes occurred relatively slower in the real American middle class- as well as the Miller householdthan the way they were demonstrated in various publications. There are many factors that powerfully contribute to how a person will use a space, including that person's education, taste, income, desire and feelings.

Another significant point of this study is the necessity of such modernity studies to be conducted properly considering the fact that each region has its own modernism parameters and this occurs in different forms. Therefore, in considering that this study is carried out in the southern region of the United States, different results could be obtained for different families in the northern region. In this context, it can obviously be said that each place, region or city has its own modernity parameters. 
We also investigate the facts behind the rearticulation of traditional domestic values and ideals on a middle-class postwar house.

This study is also important to contribute to the literature just because unlike the typical narratives of architectural history, which normally includes well-known architects, wealthy clients and sensational houses, this study takes an approach that is far less glamorous but certainly more relevant to a broad spectrum of American lives in 1950s. The study focuses primarily on middle-class houses-those are, houses that were not commonly designed by architects as custom homes which were not designed by architects as custom homes but instead, were designed and built by builders or developers for a mass audience or by homeowners for themselves.

Shortly, this study has the potential to broaden our understanding of the 1950 's domestic life, as well as influence how we approach other domestic studies, modernist architecture, and modern lifestyles.

\section{BIBLIOGRAPHY}

ATTFIELD, J. (2002) Moving Home: Changing Attitudes to Residence and Identity, The Journal of Architecture, 7 (3) 249-62.

BARRY, J. A. (1955) An Interview with the People who Live in This House, House Beautiful, 97 (10) 182.

BERGER, A. A. (1996) Narratives in Popular Culture, Media, and Everyday Life, Sage Publications Inc., Thousand Oaks.

BRYSON, B. (2010) At Home: A Short History of Private Life, Anchor Books, New York.

CIERAAD, I. (1999) At Home: Anthropology of Domestic Space, Syracuse University Press, New York.

DOMIN, C., KING, J. (2002) Paul Rudolph, The Florida Houses, Princeton Architectural Press, New York.

HARCOURT, H. (1889) Home life in Florida, J.P. Morton \& Company, Louisville, Kentucky.

HARRIS, D. (2013) Little White Houses: How the Postwar Home Constructed Race in America (Architecture, Landscape and American Culture), University of Minnesota Press, Minneapolis.

HOWEY, J. (1995) The Sarasota School of Architecture: 1941-1966, MIT Press, Cambridge.

JACKSON, L. (1994) Contemporary: Architecture and Interiors of the 1950s, Phaidon Press Ltd., London.

KENT, S. (1990) Domestic Architecture and the Use of Space: An Interdisciplinary Cross-cultural Study, Cambridge University Press, New York.

KUONEN, C. D. (2003) The Search for Authenticity: Developing a 21st Century Regional Modernism in Florida's Domestic Architecture, unpublished Master's Thesis, School of Architecture, University of Florida, Florida.

LANE, M. B. (2007) Housing and Dwelling Perspective on Modern Domestic Architecture, Routledge, London. 
LEHMANN, J. D. (1963) Downtown Gainesville, City and Regional Planning Department, Florida.

MAY, E. T. (1998) Homeward Bound: American Families in the Cold War Era, Basic Books, New York.

Mid-century Modern Architecture in Northeast Florida (2008) American Institute of Architects, Atlantic Beach, FL: AIA Jacksonville.

MINTZ, S., KELLOGG, S. (1988) Domestic Revolutions A social History of American Family Life, The Free Press, New York.

MOEN, T. (2006) Reflections on the Narrative Research Approach, International Journal of Qualitative Methods 5 (4) 56-69.

PARKER, A. B. (1965) You and Architecture, Delacorte Press, New York.

PEREZ-MENDEZ, A. (2002) Craig Ellwood: In the Spirit of the Time. Editorial Gustavo Gili, Barcelona.

PRICE, K. M. (1979) A Home for the Successful Businesman, Florida Trend Magazine (33).

RIESSMAN, C. K. (1993) Narrative Analysis, Sage Publications, London.

RITCHIE, D. A. (2003) Doing Oral History, Oxford University Press, New York.

SAND, J. (2003) House and Home Architecture, Domestic Space and Bourgeois Culture, 1880- 1930, Harvard University Press, Cambridge.

YOUNG, W. H., YOUNG, N. K. (2004) The 1950s (American Popular Culture Through History). Greenwood Press, Westport Connecticut, London.

WERTSCH, J. V. (1991) Voices of the Mind: A Sociocultural Approach to Mediated Action. Harvard University Press, Cambridge.

WHITE, R. (1998) Remembering Ahanagran: Storytelling in a Family's Past. Hill \& Wang, New York.

Alınd1: 23.08.2013; Son Metin: 21.01.2014

Anahtar Sözcükler: Ev; barınma kültürü ve mekan; sözlü tarih; öyküleme araştırma teknikleri.

\section{DÜNYA SAVAȘI SONRASI BARINMA KÜLTÜRÜNDE DEĞİŞIM: MILLER EVI, GAINESVILLE, FLORIDA}

Çalışma, II. Dünya Savaşı'ndan sonra barınma kültüründe yaşanan değişimin, kentsel ölçekte gerçekleşen değişimden, sosyo-kültürel alanda yaşanan yeniliklerden, teknolojik gelişmelerden ve tüm bunlara bağlı olarak evdeki gündelik yaşam pratiklerinden bağımsız okunmasının mümkün olamayacağı ön görüsüyle kurgulanmıştır.

Bu kapsamda, çalışmada ev ve içindeki yaşam arasındaki o güçlü bağ vurgulanarak yazıla gelen "konut modernleşmesine" farklı bir bakış açısı ile konutların salt dış biçimlenmesine ilişkin tektonik ve planimetriden oluşan anlatıların ötesinde, doğrudan doğruya ev halkı ve onların barınma deneyimleri üzerinden bir modernlik araştırması yapılarak evin konumlandığ1 Florida eyaletine ait yerel değerlerin, öznelerin alışkanlıklarının ve geleneklerin de gözetildiği, bir barınma kültürü anlatısı hedeflenmiştir. 
Çalışmada inceleme konusu olarak Amerika Birleşik Devletleri'nin Gainesville, Florida eyaletinde, 1950 'de inşa edilen orta sınıf bir aile olan Miller Ailesi'ne ait "Miller Evi" incelenmiştir.

Çalışmada özellikle "mekan" ve "barınma pratikleri" arasındaki karmaşık ilişki, mimarlık Tarihi araştırmalarında sıklıkla başvurulan nitel araştırma tekniklerinden; yazın taraması, gözlem ve belgeleme ile birlikte sözlü tarih ve öyküleme araştırma teknikleri çerçevesinde çözümlenmeye çalışılmıştır. Çalışma kapsamında 1950'leri hatırlayan ve yaşamının geçtiği mekânlara ait ayrıntılı bilgiye sahip Miller Ailesi'ne ulaşılmış ve aileden elde edilen belge ve kayıtlara ek olarak, eve ilişkin öznel bilgiler de değerlendirilmiştir. Böylelikle konu ile ilgili nesnel ve öznel veriler sistemli bir biçimde örtüştürülmek suretiyle mekansal değişim incelenmiştir.

Bu kapsamda barınma kültüründeki değişimi, kullanıcı özneyi merkeze alarak günlük yaşamla birlikte geniş bir bakış açısı ile inceleyen çalışmanın, mimarlık tarihi yazınında modernlik okumalarında benzer çalışmalar yapacak araştırmacılar için yeni tartışma malzemesi ve temel kaynak oluşturacağına inanılmaktadır.

Çalışmanın bir diğer önemli sonucu ise, 1950'lerdeki modernlik söylemlerinin yazıla geldiği gibi döneme ait dergi ve gazetelerde anlatılan varlıklı ailelerin barınma deneyimleri çerçevesinde modernlik çözümlemesi yerine, dönemin orta-sınıf evlerinden biri olan Miller Evi incelenerek ortasınıf barınma ve konut kültürü üzerine yapılan araştırmalara da katkı sağlaması öngörülmektedir. 1950'lerde yayın organlarında söz edilen "Amerikan rüyası" ve "ideal ev" tanımlamaları çerçevesinde ele alınan ev yaşantısının, gerçekte geleneksel barınma pratikleriyle yeni yaşam modelleri arasında gelişen bir barınma kültürü çerçevesinde geliştiği ortaya konulmuştur. Yayınlardaki bu çabaların gerçek hayattaki mekânsal yansıması göreceli olarak daha yavaştır. Çünkü tanımlanan ideal ev, gerçek hayatta kullanıcının sosyal ve kültürel değerleri çerçevesinde gelir, eğitim düzeyi, kişisel tercihleri ve geleneksel alışkanlıklarına göre yeniden biçimlenmektedir.

Çalışmanın bir diğer önemli sonucu da, her bölgenin kendine ait modernlik parametrelerinin olduğu ve farklı zamansallık ve boyutta gerçekleştiği göz önüne alınarak modernlik okumalarının yapılması gerektiğidir. Bu çalışma Amerika'nın güney bölgesinde gerçekleştirilirken kuzeyindeki farklı aileler için farklı sonuçlar elde edileceği düşünülmektedir.

Çalışma, yapılan çözümlemeler ile sunduğu bilgilerle, 1950'lerdeki barınma deneyimleri, yaşam koşulları ve standartlarına dair yeni tartışma malzemeleri oluşturmaktadır.

FILIIZ SÖNMEZ; B.Arch., M.Arch., PhD.

Received her M. Arch. degree from the Department of Architecture at METU in 2006; completed her Ph.D. in Architectural History at YTÜ in 2012. Studied at the University of Florida as a visiting scholar in 2010. Her areas of interests are domestic architecture and theory of modern architecture. sonmezfiliz5@gmail.com 
